\title{
Pulmonary Deposition of a Fly Ash Aerosol by Inhalation
}

\author{
Isamu TANakA ${ }^{1}$, Koji MATSUnO ${ }^{2}$, Yasushi KODAmA ${ }^{2}$ and Takashi AkIYAMA ${ }^{1}$ \\ ${ }^{\prime}$ Department of Environmental Health Engineering, School of Medicine, University of Occupational and \\ Environmental Health, Japan. Kitakyushu 807, Japan \\ ${ }^{2}$ Department of Environmental Health, School of Medicine, University of Occupational and \\ Environmental Health, Japan. Kitakyushu 807, Japan
}

\begin{abstract}
Disease-free Wistar male rats were exposed to fly ash at an average concentration of $73 \mathrm{mg} / \mathrm{m}^{3}$ for 23 hours per day, 5 days per week for one month. The aerosols were characterized with respect to both physical and chemical properties. The exposed rats were sacrificed to measure the lung burden of fly ash. The lung burden of fly ash was estimated by the measurement of aluminium content in the lung, the average being $9.4 \mathrm{mg}$ in exposed rats. The apparant deposition fraction was $1.8 \%$.
\end{abstract}

Key words: fly ash, inhalation toxicity, health effect, dust.

(Received 15 August 1983)

\section{Introduction}

Due to the shortage of energy resources, the avoidance of too much dependence on petroleum energy has increased the use of coal in power plants. Fly ash aerosols are carried with the exhaust gases during the combustion of coal. Fly ash is removed by electrostatic precipitators, but some of it escapes these devices and is released into the environment via the smoke stack. The amount of fly ash generated in coal combustion may be several hundred times more than that in oil burning, which will cause serious health problems.

However, there are few reports on the inhalation toxicity of fly ash aserosol. Fisher \& Wilson (1980) investigated the effects of fly ash on the macropharge function and progenitors of mice and showed that the macropharge phagocytosis was significantly depressed. The results of their studies also indicated hematogenous recruitment of. lung macropharges in response to particulate insult. Chronic inhalation exposure of nickelenriched fly ash by hamsters was investigated by Wehner et al. (1981). Lung weights were higher than those of the controls, and no statistically significant carcinogenesis was observed. Hill \& Hobbs (1982) showed that fly ash was not found to be cytotoxic in vitro. Raabe et al. (1982) investigated the chronic inhalation of fly ash by rats. Lung burdens of up to $4 \mathrm{mg}$ of fly ash were found, when the average exposed concentration was $4.2 \mathrm{mg} / \mathrm{m}^{3}$ for 8 hours per day for up to 180 consecutive days. However, there were no apparent untoward health effects from inhaled fly ash, since the observed differences between exposed and control rats did not constitute an adverse response. 


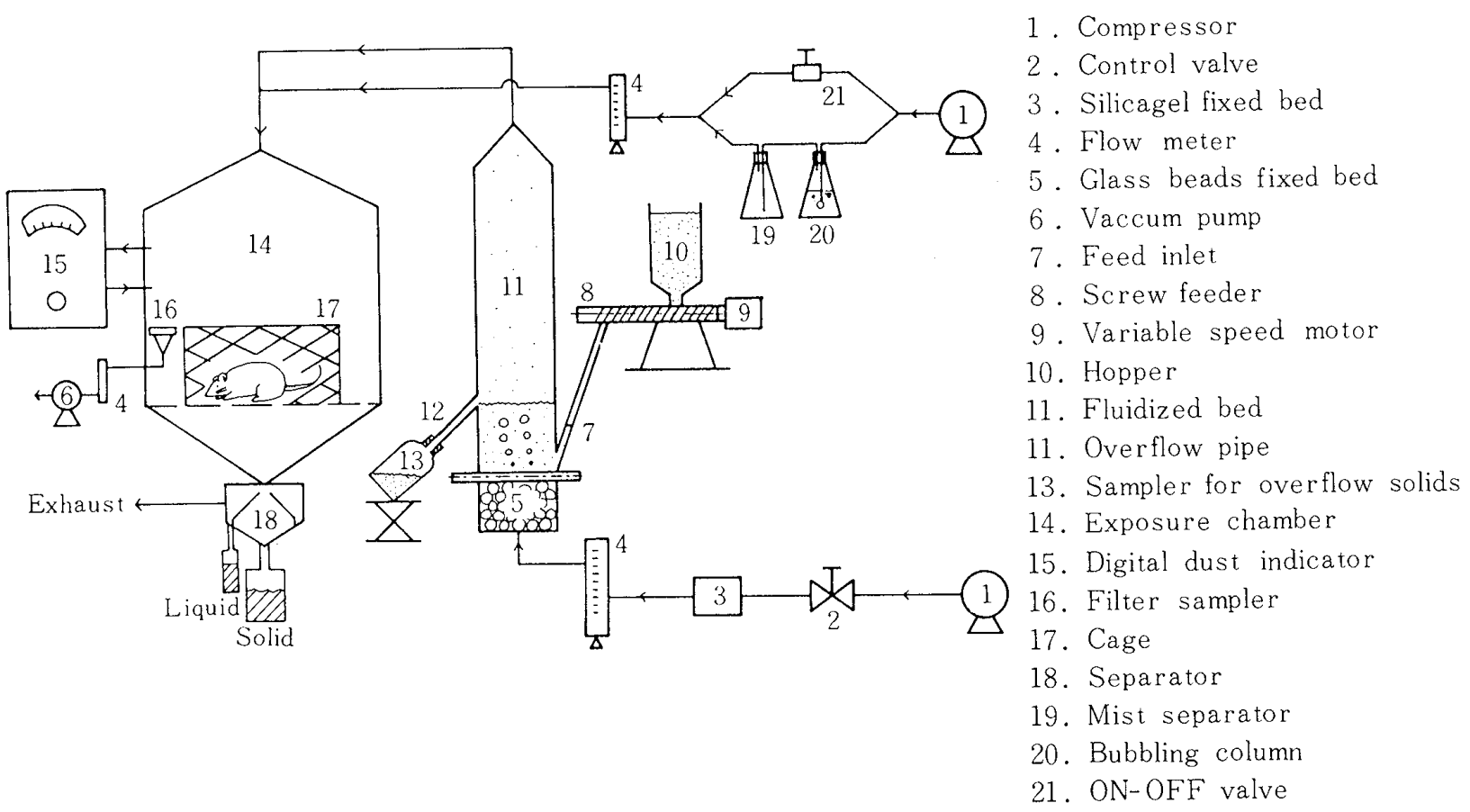

Fig. 1. Schematic diagram of dust exposure system.

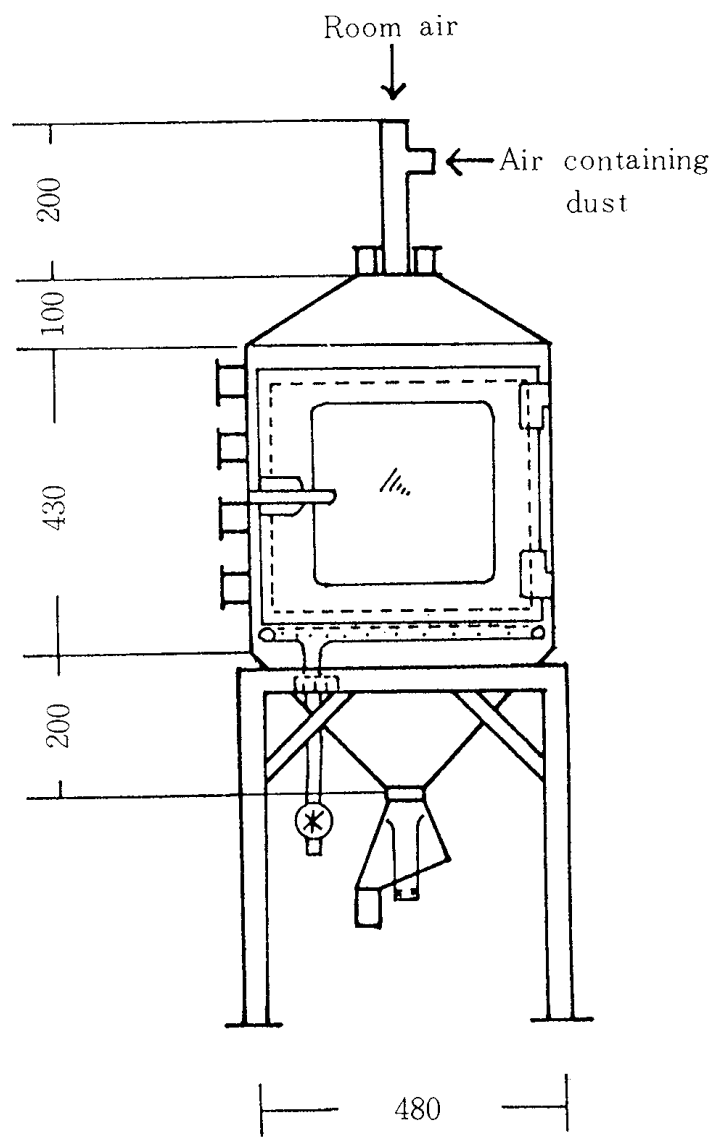

Fig. 2. Exposure chamber. 
This paper reports on the operational conditions of the chamber to be used to expose rats to fly ash aerosols, and the chemical analysis of fly ash and the lung burden of fly ash during a one-month exposure.

The health effects and other pertinent data will be examined in a later series of experiments.

\section{Experiment}

A schematic diagram of the inhalation system is shown in Fig. 1. It consists of a dust generator, exposure chambers and gas-liquid-solid separators. A continuous fluidized bed was used as the dust generator. This generator, which was developed by Tanaka \& Akiyama (1983), has the following advantages:

1) It is possible to operate for a long time, i. e., several years.

2) The dust concentration can be changed arbitrarily, i. e., $0.01 \mathrm{mg} / \mathrm{m}^{3}$ to $10 \mathrm{~g} / \mathrm{m}^{3}$.

3) Many kinds of aerosol particles can be generated.

4) Maintenance and operation are easy.

Dust from the generator was introduced into the exposure chamber and then was mixed with room air. The dust concentration in the exposure chamber was monitored continuously by a light scattering method and was adjusted automatically by the on-off control of the screw feeder. Details are shown in Fig. 2 of the conventional type exposure chamber. The air flow was downward and laminar with a volume of $0.1 \mathrm{~m}^{3}$.

Mass concentration of fly ash was measured by an isokinetic dust sampler and the size distribution of the aerosol was measured by an Andersen sampler. Only room air was introduced into the control chamber. The flow rate was the same as that in the dust exposure chamber. The humidity of the exposed air was kept constant by a humid-

Table 1. Operating conditions and performance data

\begin{tabular}{lcc}
\hline \multicolumn{1}{c}{ Condition } & $\begin{array}{c}\text { Exposure } \\
\text { chamber }\end{array}$ & $\begin{array}{c}\text { Control } \\
\text { chamber }\end{array}$ \\
\hline Volume $\left(\mathrm{m}^{3}\right)$ & 0.1 & 0.1 \\
Air $\left(\mathrm{m}^{3} / \mathrm{min}\right)$ & 0.05 & 0.05 \\
Differential pressure from & $10-50$ & $10-50$ \\
$\quad$ atomospheric pressure (Pa) & $27 \pm 2$ & $24 \pm 1$ \\
Temperature $\left({ }^{\circ} \mathrm{C}\right)$ & $52 \pm 6$ & $50 \pm 3$ \\
Relative humidity (\%) & 250 & 0 \\
Fly ash concentration by light & & $0.095-0.1$ \\
scattering method (count $/ \mathrm{min})$ & $0.075-0.1$ & $<0.5$ \\
$\mathrm{CO}_{2}$ concentration (\%) & $<0.5$ & \\
$\mathrm{NH}_{3}$ concentration (ppm) & &
\end{tabular}


ity controller and the pressure in the chambers was kept at the atmospheric pressure plus $50 \mathrm{~Pa}$ (pascal). The operating conditions and the performance data of this study are shown in Table 1.

Test substances

The dust used was fly ash distributed by the Association of Powder Process Industry and Engineering, Japan. This fly ash is the dust for industrial testing No. 5 in JIS-Z8901. The aluminium content and other elements of the fly ash aerosol was determined by an inductively coupled plasma emission spectroscopy.

Animals

The rodents used in this experiment were $270 \mathrm{~g}-310 \mathrm{~g}$ disease free Wistar male rats. The rats were randomly divided into control and test groups of 5 rats each.

Dust generation and analysis

Fly ash dust was fed at $320 \mathrm{mg} / \mathrm{m}^{3}$ from the dust generator into the exposure chamber with the feed rate being controlled by the rotating speed of the screw feeder and the air flow rate for fluidization.

The fly ash aerosol concentration in the exposure chamber was measured daily for 10 min by the isokinetic suction of air through a glass fiber filter. The glass fiber filter was weighed before and after the measurements in accordance with the standard method in JIS-Z8808. Aerosol size distribution was determined by using an Andersen cascade impactor.

Exposure

The test group was 5 rats in one cage placed in the exposure chamber and exposed 23 hours per day, 5 days per week for one month.

Chamber cleaning was performed once a day during the hour between exposure periods.

After a 21-day clearance period, the burden of fly ash was measured by chemical analysis after the rats were sacrificed.

Lung burden measurements

According to Raabe et al. (1982), some exposed animals and controls were killed by an overdose of pentobarbital and their lungs were digested for analysis of aluminium content by an atomic absorption spectroscopy. Since control aluminium lung burdens are quite small, this provided a quantitative measure of the fly ash present in lungs of the exposed animals.

In our experiments, the lungs were weighed and then treated with a mixture solution of sulfuric acid and nitric acid until the samples were completely digested. After the 


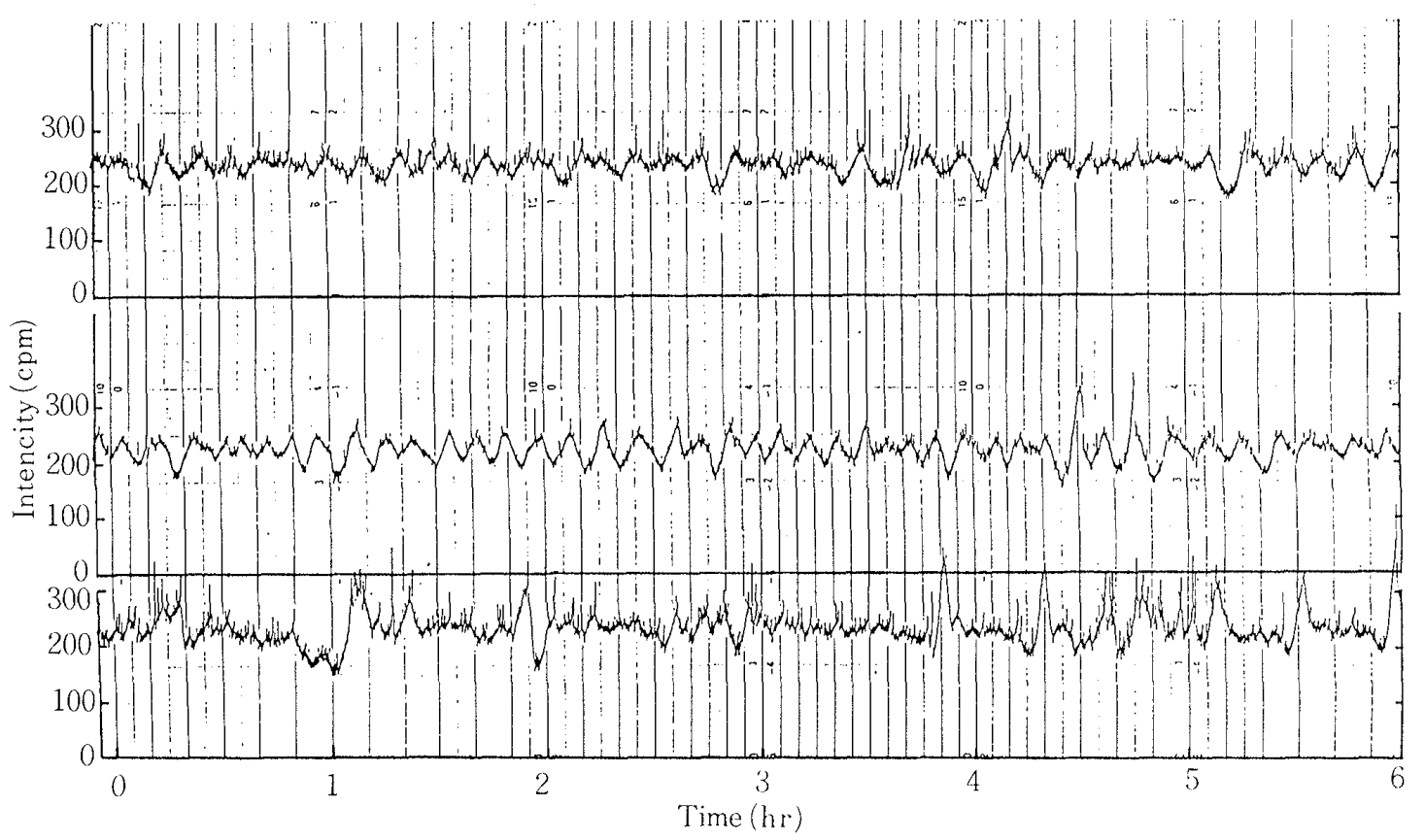

Fig. 3. Dust concentration in exposure chamber monitored by digital dust indicator (Shibata AP 632L).

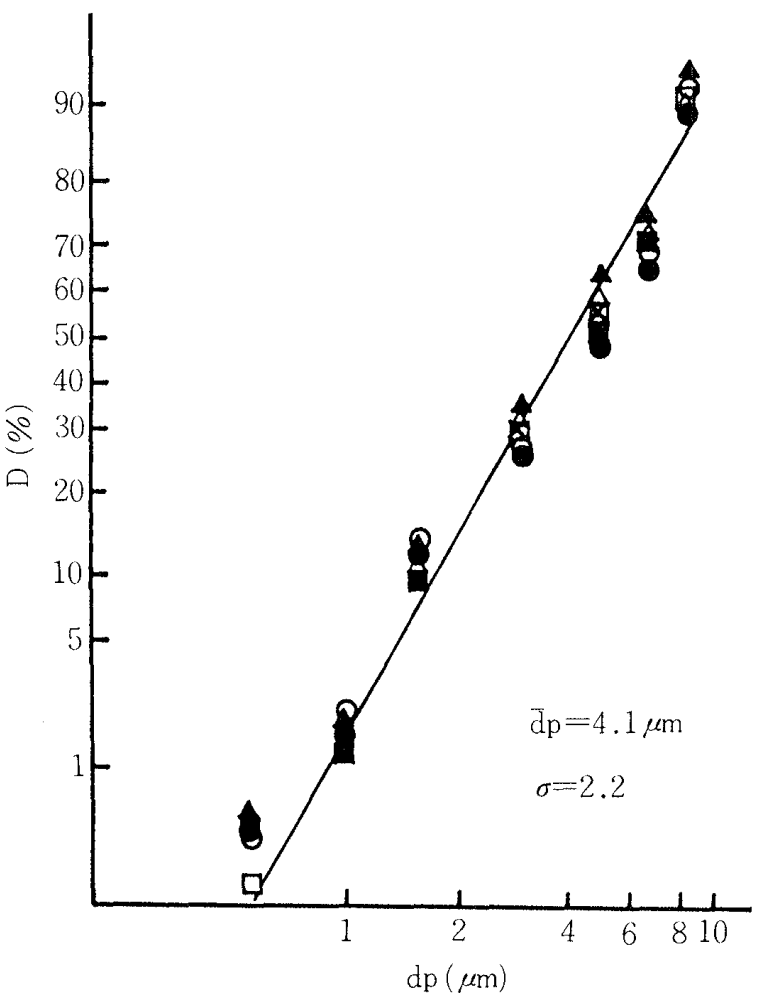

Fig. 4. Cumulative size distribution of fly ash in exposure chamber.

Aerodynamic mass median diameter : $4.1 \mu \mathrm{m}$. Geometric standard deviation: 2.2.

First day

$9: 00-10: 00$

$12: 00-13: 00$

$\times \quad 14: 00-14: 30$
Second day

$\triangle \quad 9: 00-9: 30$

$11: 30-12: 00$

$14: 00-15: 00$
Third day

$9: 00-9: 30$ 
digestion, the sample solutions were also treated with hydrochloric acid and then diluted with hydrochloric acid. Aluminium standards and the treated samples were analysed for aluminium at $309.3 \mathrm{~nm}$ by an atomic absorption spectrometry with a nitrous oxideacetylene flame.

\section{Results and Discussion}

The daily dust concentration monitored by the light scattering method is shown in Fig. 3. The figure shows a part of the results of alternative days during the experiments. The concentration of fly ash aerosol in the exposure chamber seems to be kept at constant.

The daily average mass concentration during experiments by the glass fiber filter was $73 \mathrm{mg} / \mathrm{m}^{3}$ and the standard deviation $\pm 24 \mathrm{mg} / \mathrm{m}^{3}$. This value was shown to be one-fourth that of the $320 \mathrm{mg} / \mathrm{m}^{3}$ estimated from the generation rate at the dust feeder. This suggests that the aerosol was deposited in the pipe line before reaching the exposure chamber. This ratio was much smaller than that in our previous paper (Tanaka et al., 1982). The reason for this is that the flow systems of the dust containing air are different.

The size distribution of fly ash in the exposure chamber is shown in Fig. 4. The distribution was measured at the end of one month exposure period. The value was obtained for 4 consecutive days at the same exposure conditions. No significant difference among them was found. The mass median aerodynamic diameter and the geometric standard deviation was $4.1 \mu \mathrm{m}$ and 2.2 respectively. Fig. 5 shows the dispersion of fly ash aerosol deposited on a piece of cover-glass for 1 hour in the exposure chamber. The figure indicates that the fly ash was evenly dispersed throughout the chamber. Upon close observation, however, some small particles were agglomerated and adsorbed onto the larger ones, as shown in Fig. 6.

Table 2 shows the results of chemical analysis of fly ash measured by an inductively coupled plasma emission spectroscopy.

These results are similar to that in Raabe et al. (1982). Aluminium contents in fly ash were also analysed by an atomic absorption spectrometry and was seen to be $9.7 \%$.

Table 3 shows the deposition of the exposed fly ash in rat lungs. Rat lung homogenates were prepared from some animals exposed to fly ash. The lung burden of fly ash was determined from the measured masses of $\mathrm{Al}$ in the lungs assuming $9.7 \% \mathrm{Al}$ in fly ash as shown in Table 2. Aluminium contents in the lungs of the exposed rats increased significantly. The lung burden of fly ash was divided by the calculated total mass of inhaled fly ash to yield the apparent deposition fraction. For purposes of this calculation, clearance is assumed to be negligible.

The minute volumes were calculated by the Guyton equation (Guyton, 1974) and the total volumes of air inhaled during the exposure were multiplied by the average fly ash 


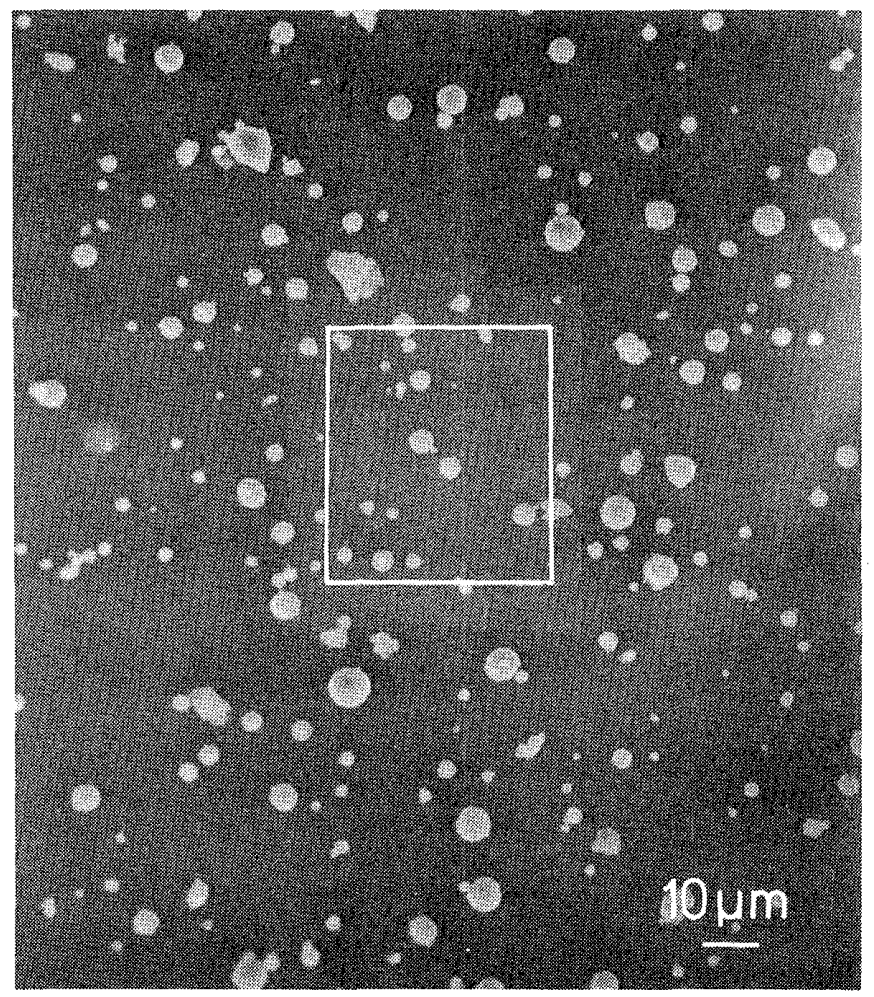

Fig. 5. A scanning electron micrograph of fly ash aerosol (Hitachi $\mathrm{S}-700$ at $25 \mathrm{KV}$ ). Scale : $10 \mu \mathrm{m}$.

A part of the square magnified in Fig. 6 for details.

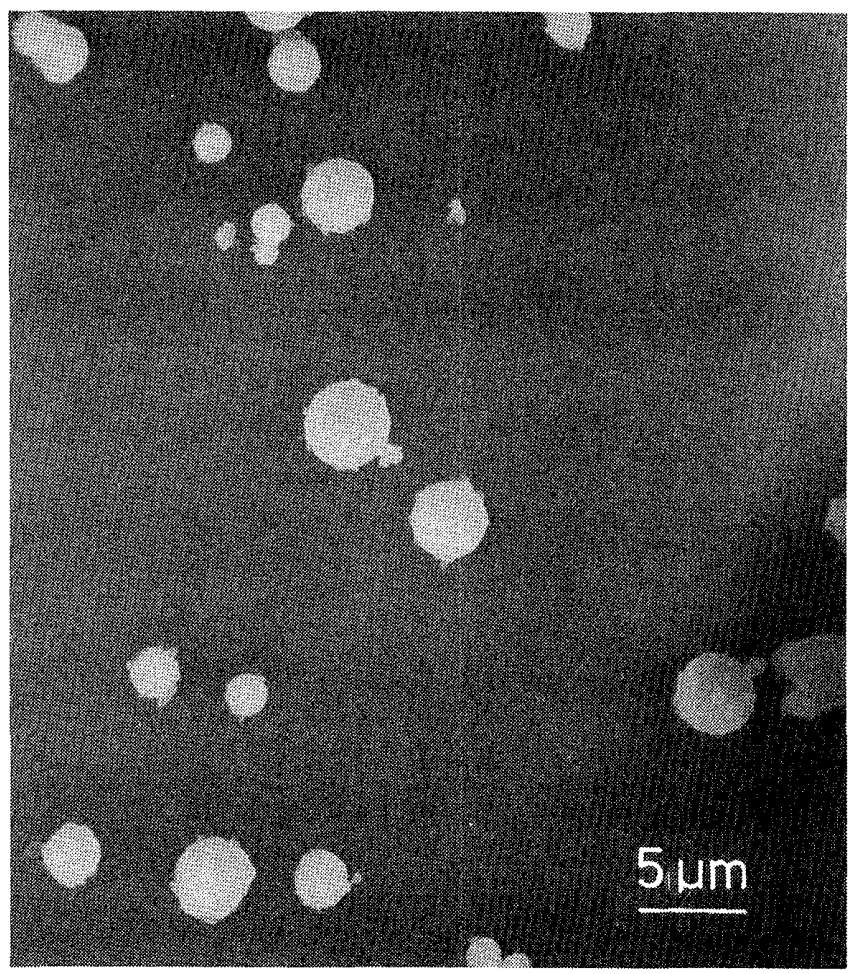

Fig. 6. A scanning electron micrograph of fly ash particles. Scale : $5 \mu \mathrm{m}$. 
Table 2. Concentration of elements in fly ash*

\begin{tabular}{|c|c|c|c|c|c|}
\hline Element & $\begin{array}{l}\text { Concentration } \\
(\mathrm{mg} / \mathrm{g})\end{array}$ & Element & $\begin{array}{c}\text { Concentration } \\
(\mu \mathrm{g} / \mathrm{g})\end{array}$ & Element & $\begin{array}{c}\text { Concentration } \\
(\mu \mathrm{g} / \mathrm{g})\end{array}$ \\
\hline $\mathrm{Al}$ & 97 & As & 86 & Mo & 36 \\
\hline $\mathrm{Ca}$ & 79 & $\mathrm{Au}$ & 15 & $\mathrm{Ni}$ & 57 \\
\hline $\mathrm{Fe}$ & 60 & $\mathrm{Cd}$ & 3.1 & $\mathrm{~Pb}$ & 92 \\
\hline $\mathrm{K}$ & 94 & $\mathrm{Co}$ & 31 & $\mathrm{Se}$ & 50 \\
\hline $\mathrm{Mg}$ & 14 & $\mathrm{Cr}$ & 97 & $\mathrm{Si}_{\mathrm{i}}$ & 456 \\
\hline \multirow[t]{3}{*}{$\mathrm{Na}$} & 13 & $\mathrm{Cu}$ & 103 & $\mathrm{Sn}$ & 40 \\
\hline & & $\mathrm{Hg}$ & $<4.0$ & Sr & 1750 \\
\hline & & $\mathrm{Mn}$ & 84 & $\mathrm{Zn}$ & 254 \\
\hline
\end{tabular}

* Disolved with $\mathrm{HCl}$.

Table $3 . \quad$ Deposition of inhaled fly ash in rats

\begin{tabular}{|c|c|c|c|c|c|c|}
\hline & $\mathrm{N}$ & $\begin{array}{l}\text { Lung weight } \\
\qquad(\mathrm{g} \pm \mathrm{SD})\end{array}$ & $\begin{array}{c}\text { Lung } \mathrm{Al} \\
\text { concentration } \\
(\mu \mathrm{g} / \mathrm{g} \pm \mathrm{SD})\end{array}$ & $\begin{array}{l}\text { Lung Al } \\
(\mu \mathrm{g} \pm \mathrm{SD})\end{array}$ & $\begin{array}{l}\text { Lung burden* } \\
\text { (mg } \pm \mathrm{SD})\end{array}$ & $\begin{array}{c}\text { Apparent deposition } \\
\text { fraction } \\
(\% \pm \mathrm{SD})\end{array}$ \\
\hline Exposure & 3 & $2.0 \pm 0.2$ & $450 \pm 80$ & $910 \pm 110$ & $9.4 \pm 1.1$ & $1.8 \pm 0.2$ \\
\hline Control & 5 & $2.1 \pm 0.4$ & $4.1 \pm 1.5$ & $8.8 \pm 3.6$ & - & - \\
\hline
\end{tabular}

* Based on $9.7 \%$ Al concentration.

concentration to yield the total mass of inhaled fly ash. The apparent deposition fraction of $1.8 \%$ in this experiment was lower than $4.7 \%$ in Raabe et al. (1982). The causes of this are the differences of the exposure conditions and the diameter of the exposed fly ash, that is, $4.1 \mu \mathrm{m}$ in this work and $1.97 \mu \mathrm{m}$ in Raabe et al.

The biochemical findings and histological changes of the rats will be reported in a following series of papers.

\section{Conclusions}

1) The daily average aerosol concentration in the exposure chamber was $73 \mathrm{mg} / \mathrm{m}^{3} \pm$ $24 \mathrm{mg} / \mathrm{m}^{3}$ (SD).

2 ) The mass median aerodynamic diameter of fly ash aerosol in the exposure chamber was $4.1 \mu \mathrm{m}$ and the geometric standard deviation was 2.2.

3 ) The dispersion of aerosol in the exposure chamber was evenly distributed.

4) The fly ash used contained toxic metals.

5 ) Lung burden of $9.4 \mathrm{mg}$ of ash was found in these experimental conditions. 


\section{Acknowledgement}

We wish to thank Mr. Onizuka of the Animal Research Center and Miss Katayama and Miss Ishimatsu who assisted in the sampling. This work was supported by a grant from Toyota Foundation.

\section{References}

Fisher, G. L.. \& Wilson, F. D. (1980) : Effects of coal fly ash and silica inhalation of macrophage function and progenitors. J. Reticuloendothl. Soc., $27: 513-524$.

Guyton, A. C. (1947) : Measurement of the respiratory volumes of laboratory animals. Am. J. Physiol., $150: 70-77$.

Hill, J.O. \& Hobbs, C. H. (1982): Comparative cytotoxicity of DQ12 quarz and fly ash particles from coal combustion. Toxicol. Lett., 10:399-403.

Raabe, O. G., Tyler, W. S., Last, J.A. et al. (1982): Studies of the chronic inhalation of coal fly ash by rats. Ann. Occupa. Hyg., 26: 189-211.

Tanaka, I. \& Akiyama, T. (1983): Development and performance of exposure chamber for long-term period. Proc. Jap. Asso. Indust. Health, 56: 240-241.

Tanaka, I., Hayashi, H., Horie, A. et al. (1982): Toxicity of a nickel oxide aerosol by inhalation. J. UOEH, $4: 441-449$.

Wehner, A. P., Dagle, G. E. \& Milliman, E. M. (1981): Chronic inhalation exposure of hamsters to nickel-enriched fly ash. Environ. Res., 26: 195-216.

\section{フライアッシュ粒子の肺内沈着}

田中 勇武 ${ }^{1}$ 松野 康二 ${ }^{2}$ 児玉 泰 ${ }^{2}$ 秋山 高 ${ }^{1}$

1産業医科大学労働衛生工学教室 2産業医科大学衛生学教室

要旨：フライアッシュ粒子のラットへの吸入曝露実験装置を試作し，その性能およびラットへの 曝露結果について調ベた。フライアッシュ粒子は，連続式流動層方式の発塵装置か ら，1日23時間，1 週間に5日で 1 力月間曝露された。曝露されたフライアッシュ濃度は, 光散乱法で常時モニタ一され，かつその濃度をコントロールすることによって，ほぼ一定 に保たれた。この間の曝露濃度は, 等速吸引法で測定し, 平均 $73 \mathrm{mg} / \mathrm{m}^{3}$ であった。また, 空気力学的メディアン径は $4.1 \mu \mathrm{m}$ であった. ラットの肺内沈着量を推定するため, フラ イアッシュ粒子の主成分の1つであるアルミニウム量を测定し，フライアッシュ粒子中の

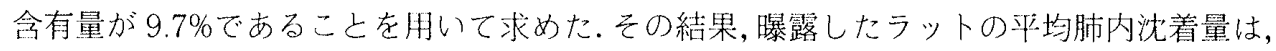
$9.4 \mathrm{mg}$ であり，肺内沈着䧱は，1.8\%であった。

J. UOEH（産業医大誌），5(4)：423-431 (1983) 